\title{
SUVREMENA TURISTIČKA IZGRADNJA NA PODRUČJU ROVINJA - ZONA MONTE MULINI, ISTRA
}

\author{
CONTEMPORARY TOURISM FACILITIES IN ROVINJ \\ AREA - MONTE MULINI ZONE, ISTRIA
}

\author{
Stefan Krošnjak*, Iva Mrak*, Cela Matan*, Marko Franković*
}

\begin{abstract}
Sažetak
U radu je dan povijesni pregled razvoja turizma u Rovinju te je razvoj zone Monte Mulini analiziran kao posebno zanimljiv s aspekta novije hotelske izgradnje $u$ Hrvatskoj. Na relativno malom području uz rub parka šume Zlatni Rt u posljednjih desetak godina sagrađena su čak tri visoko kategorizirana hotela na mjestu postojećih te je renoviran hotel Eden arhitekata Bartolića i Begovića. U radu se analiziraju osnovne karakteristike nove gradnje i rekonstrukcije hotela Eden te urbanističke i arhitektonske karakteristike ove zone.
\end{abstract}

Ključne riječi: hoteli, Rovinj, Monte Mulini, Hotel Eden, Hotel Lone, Hotel Park

\begin{abstract}
The paper presents an overview of the historic development of tourism in Rovinj, Croatia. The development of Monte Mulini area is analysed as particularly interesting from the aspect of recent hotel construction in Croatia. On the relatively small area near the edge of forest park Zlatni Rt, in last ten years three highly categorised hotels were built on the area of existing hotel buildings, and the hotel Eden, designed by architects Bartolić and Begović, has been reconstructed. Urban and architectural characteristics of the area are analysed, as well as new construction and reconstruction characteristics of existing hotels.
\end{abstract}

Key words: hoteli, Rovinj, Monte Mulini, Hotel Eden, Hotel Lone, Hotel Park

\footnotetext{
*Sveučilište u Rijeci, Građevinski fakultet, Radmile Matejčić 3, 51000 Rijeka

E-mail: \{stefan.krosnjak\}@student.uniri.hr;

\{iva.mrak,cela.matan,marko.frankovic\}@gradri.uniri.hr
} 


\section{Uvod}

Zahvaljujući posjetima termalnim kupalištima imućnijih slojeva stanovništva te sportskim događanjima onih siromašnijih stanovnika, prvi poznati oblici turizma u Istri pojavljuju se već u doba antike. U srednjem vijeku se najviše putuje radi hodočašća pa su luke važne punktovi, dok se u 19. stoljeću razvija moderni turizam čiji rast traje do Prvog svjetskog rata. Uvođenjem turističkog parobroda od Trsta do Pule počinje izletnički i kulturni turizam (1828.), a ovaj razvoj prati pojava tiskanja turističkih vodiča za Pulu i Poreč (1845.) Pred kraj 19. stoljeća razvijaju se zdravstveni, kupališni, lovni i aristokratski turizam, a tijekom 20. stoljeća sportskorekreacijski, nautički, masovni, kongresni, naturistički, ekološki i drugi oblici turizma. Važnu ulogu u prostornom razvoju turizma ima izgradnja željezničke pruge koju prati izgradnja brojnih hotela (npr. hotel Brioni u Puli) $[1,2,3,4,5,6]$. Nakon raspada Austro-Ugarske, Istra je postala dio Kraljevine Italije te turizam stagnira. U tom razdoblju bitniji turistički objekti bili su: u Rapcu hotel Citta' di Trieste i Trieste, u Umagu hotel Roma, u Puli hoteli Bologna, Carnaro, Centrale, Milano, Miramar i Moncenisio, u Umagu hoteli i vile Albergo Leon d'Oro, Albergo San Marco, Villa Miramare, Villa Mare i Villa al Greeham. Nakon Drugog svjetskog rata, turizam doživljava procvat, a pokreću se i neki do danas poznati lanci (Riviera, Plava laguna, Rabac...)[2]. Osnovna karakteristika ovog perioda je velika izgradnja turističkih objekata i turizam u ljetnim mjesecima s nižom kvalitetom smještaja. Radi stagnacije turizma tijekom Domovinskog rata, hoteli su krajem 1990-ih bili u lošem stanju. Nakon rata provodi se obnova hotelskih i drugih turističkih objekata.

U Rovinju se turizam naglo razvijao od 1950-ih (kao i u ostatku Jugoslavije), prvo kao sindikalno, dječje i „omladinsko“ ljetovalište te umjetnička kolonija, a nakon toga se ulaže u izgradnju smještajnih objekata. Tako nastaju kompleks hotela Eden, Montauro i Lone te turistička naselja Monsena i Valalta [1]. 1960-ih se obnavlja gradska jezgra i grade dvije depandanse „Monte Mulini“ (1963.). Do 1990-ih razvoj turističke infrastrukture je intenzivan, a obnova turističkih objekata se pojačava od početka 2000-ih. Danas se u Rovinju nalazi trinaest hotela (Adriatic, Angelo D’Oro, Arupinium, Butique hotel Delfin, Eden, Island hotel, Island hotel Katarina, Lone, Monte Muilini, Hotel Park, Family hotel Amarin, Vila Lili i Vila Valdibora), tri turistička naselja (Amarin, Valalta FKK i Villas Rubin) i sedam kampova (Amarin, Mon Paradis, Polari, Porton Biondi, Ulika, Valalta FKK, Vestar) [4,7]. 


\section{Metodologije i materijali}

U radu se analizira evolucija zone Monte Mulini od prve izgradnje hotela niže kategorije, do današnjih suvremenih hotela visokog standarda. Posebno se analiziraju i uspoređuju osnovne karakteristike četiri hotela zone Monte Mulini u Rovinju (urbanističko rješenje, prostornofunkcionalna organizacija, konstrukcija, standard, odnos s vanjskim prostorom, oblikovanje, materijal). Tijekom izrade rada analizirana je literatura (novinski i stručni članci te znanstveni radovi), projektna dokumentacija, napravljeni izvidi na terenu te izrađene analitičke skice kako bi se utvrdile glavne prostorno-funkcionalne karakteristike novih građevina.

\section{Hotelska izgradnja i obnova u zoni Monte Mulini}

Danas se Grad Rovinj ističe u Istri pa i u Hrvatskoj svojom ponudom hotelskog smještaja, posebno ponudom visokokategoriziranih hotela kao što su Lone, Eden, Monte Mulini i Park. Kategorizacija hotela od četiri i više zvjezdica postignuta je rušenjem starih i izgradnjom novih hotela te adaptacijom hotela Eden radi podizanja standarda.

\subsection{Zona Monte Mulini}

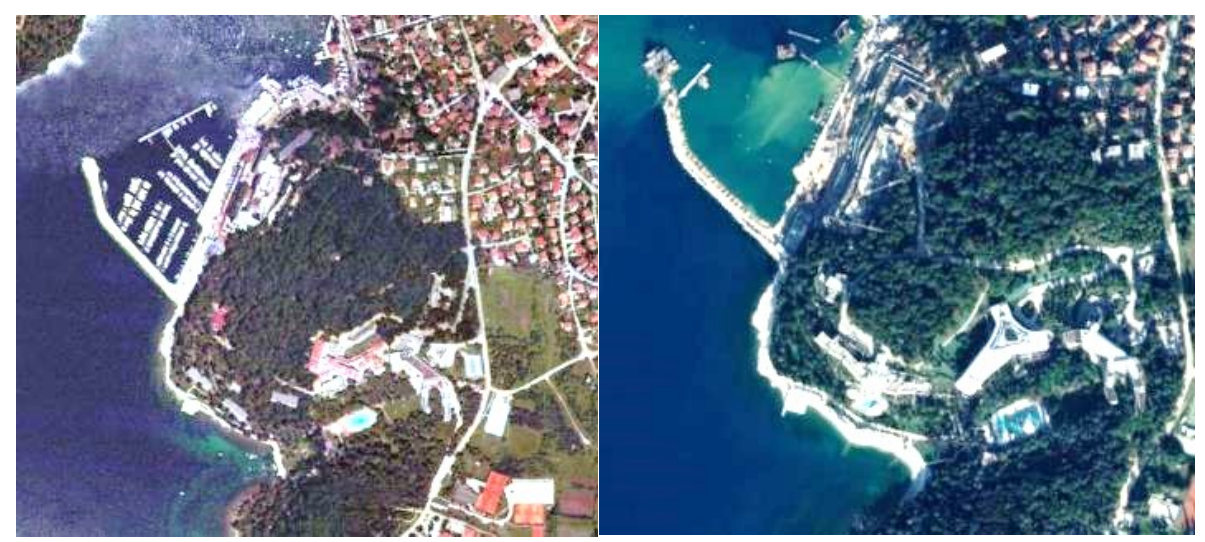

Slika 1. Zona Monte Mulini u prikazu iz DPU zone Mulini 2006. - lijevo, zračna snimka današnjeg izgleda zone - desno [8,9]

Zonu Monte Mulini (Slika 1) je početkom 20. stoljeća počeo uređivati poduzetnik njemačkog podrijetla Johan Georg Hütterott na predjelima Zlatni rt, Montauro, Škaraba, Monvi i Monte Mulini južno od centra grada (ukupno 90 hektara) s idejom izgradnje turističkog i klimatološkog lječilišta [10]. 
Nakon Drugog svjetskog rata, dijelom slijedeći ovu viziju, u ovoj se zoni grade hoteli Park, Eden, Monte Mulini i Montauro koristeći resurse kultiviranog parka šume Zlatni Rt koju je u nasljedstvo Rovinju ostavio upravo Hütterot. U 21. stoljeću, formiranjem poduzeća Maistre d.d., ulažu se velika sredstva u rekonstrukciju postojećeg hotela Eden i izgradnju novih hotela na mjestu postojećih te u uređenje plaže Mulini. U samo nekoliko godina, zona Monte Mulini pretvorena je, prema kategorizaciji novih hotela [11,12], u ekskluzivno turističko odredište.

Zona Monte Mulini nalazi se uz more te je udaljena nekoliko minuta hoda od centra Rovinja i park-šume Zlatni Rt. Park šuma i šetnica uz more uređene su kao rekreacijska zona sa stazama i šetnicom dugom nekoliko kilometara, a kroz šumu je zabranjen promet vozilima, što je čini oazom mira uz gradsku jezgru. DPU turističke zone Monte Mulini ne dozvoljava gradnju novih objekata osim popratnih sadržaja tako da su sva 4 hotela okružena šumom čija je površina smanjena povećanom površinom novih hotela [5]. Kolno-pješački pristup do svih hotela moguć je ulicom Luje Adamovića koja odvaja stambenu zonu grada od turističke ili pješačkim pristupom s mora.

Hotel Eden temeljito je rekonstruiran i po kvaliteti pripada cjenjenijim hrvatskim hotelima, Lone je prvi dizajnerski hotel u Hrvatskoj, hotel Monte Mulini spada u vrh svjetske hotelske ponude, a na mjestu hotela Park gradi se novi hotel također znatno povećanog kapaciteta i kategorizacije [8].

Ispred hotela Monte Mulini, Lone i Edena nalazi se Plaža Mulini. Nekada se ova plaža zvala „Moulin Rouge“ te je kao gradska plaža vjerojatno bila uređena 1960-ih. Današnja plaža Mulini uređena je prema projektu Studija 3LHD iz 2013.-14. godine. Između hotela i plaže prolazi šetnica koja povezuje stari grad Rovinj i park Punta Corrente.

\subsection{Hotel Eden}

Kupališni hotel Eden, djelo Ive Bartolića i Miroslava Begovića izgrađen početkom 1970-ih [13], trenutno je jedini hotel u zoni koji nije doživio veće izmjene vanjskog oblikovanja iako je izvedeno nekoliko zahvata adaptacije (npr. prilagodba soba današnjem standardu i izvedba staklene fasade) [14].

Hotel je razvedenog volumena, na šest etaža, jednostavne funkcionalne organizacije: u suterenskoj etaži nalazi se gospodarski trakt, u prizemlju društveno-javni i upravni trakt, dok je smještajni trakt na preostale četiri etaže iznad prizemlja organiziran kao dvotrakt i jednotrakt. Vertikalna komunikacija postavljena je na spoju krakova volumena te rubno. Sobe su orijentirane istočno $s$ pogledom na šumu i zapadno s pogledom prema moru.

Danas je hotel Eden kategoriziran s četiri zvjezdice [12] zahvaljujući adaptaciji izvedenoj 2016.-2017. prema projektu poduzeća AD d.o.o. Adaptacija je obuhvaćala dvorišni dio smještajnih etaža $s$ jednostranim 
galerijskim hodnicima (južni krakovi). Uređeno je 325 soba visokog standarda, ukupne površine $11.530 \mathrm{~m}^{2}$. Zahvati na smještajnom dijelu prvenstveno su obuhvatili zatvaranje dvorišnog pročelja galerijskog hodnika aluminijskom staklenom ovješenom fasadom bez promjene postojećih gabarita zgrade. U ostatku smještajnog trakta proveli su se radovi održavanja: zamjena dotrajale stolarije te poboljšanje protupožarnih karakteristika zgrade dodavanjem stubišta.

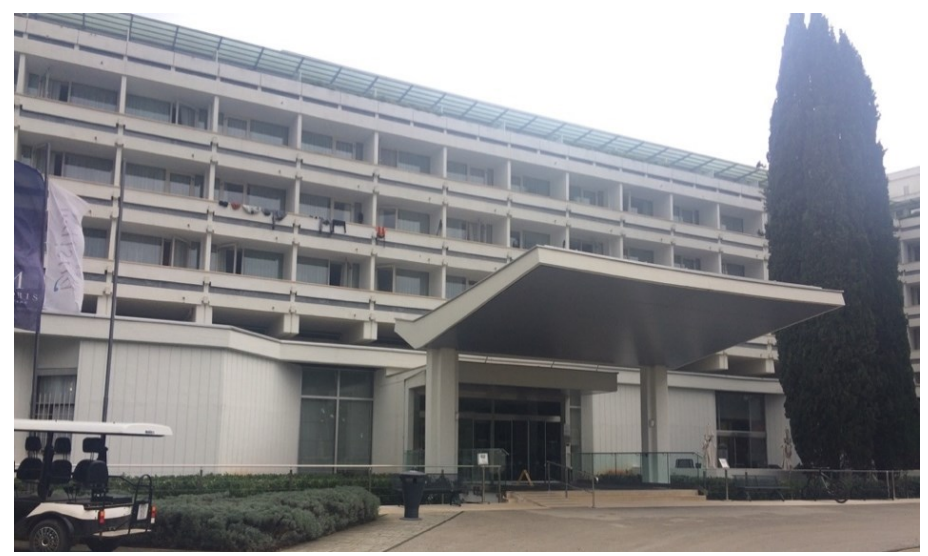

Slika 2. Ulaz hotela Eden (Krošnjak, S.) [14]

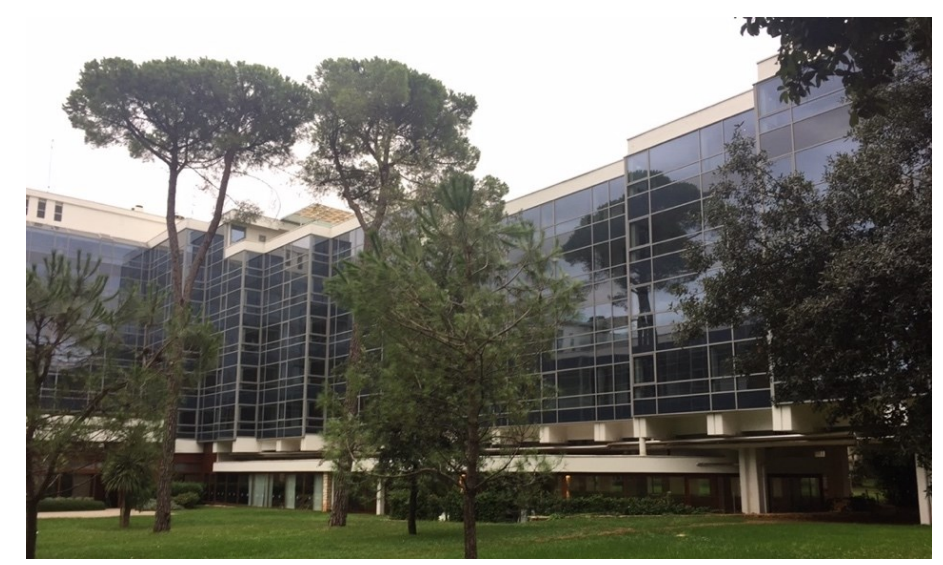

Slika 3. Staklena fasada na obnovljenom dijelu hotela (Krošnjak, S.) [14]

U suterenskoj etaži nalazi se wellness, rekonstruiran 2012. prema projektu poduzeća 3LHD iz Zagreba. Na prizemnoj etaži su konferencijska sala veličine $250 \mathrm{~m}^{2}$ (do 300 osoba) i sala za sastanke veličine $50 \mathrm{~m}^{2}(20$ osoba). Unutar glavnog hola nalazi se sala s pozornicom koja može ugostiti manje predstave.

U vanjskom prostoru hotela nalazi se bazen s popratnim sadržajima koji je otvoren i gostima hotela Lone. Uz zajednički bazen uređeno je i sunčalište 
na 6 zelenih platoa te manji objekti poput info-punkta, otvorenog bara, kabina za masažu, servisnog prostora, tuševa, kabina itd.

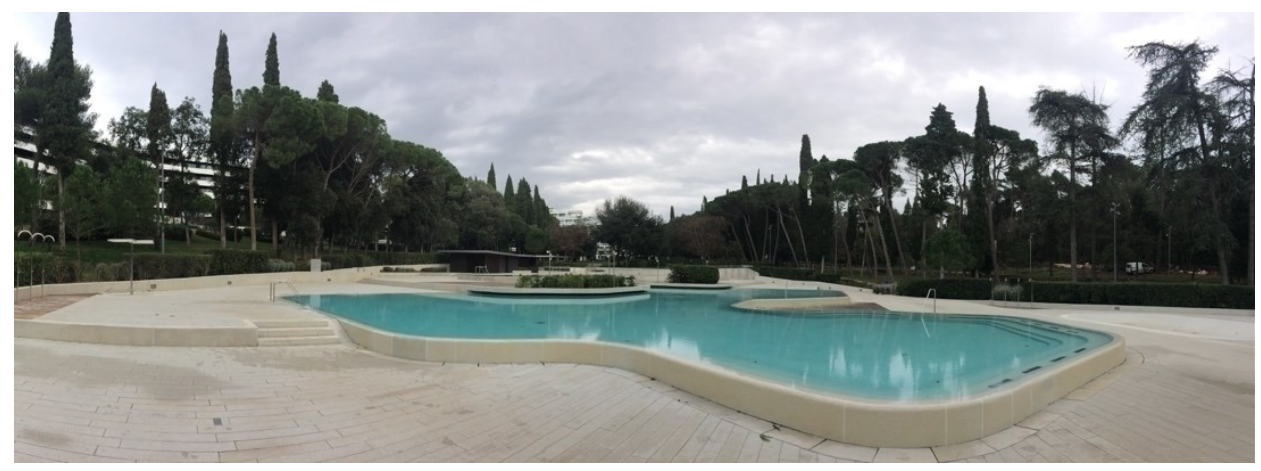

Slika 4. Zajednički vanjski bazen hotela Eden i Lone (Krošnjak, S.) [14]

\subsection{Hotel Lone}

Današnji hotel Lone nastao je na mjestu bivšeg hotela Montauro (sagrađenog 1982. prema projektu nepoznatog autora). Hotel Lone projekt je Studija 3LHD izrađen u suradnji s Arhitektonskim ateljeom Hržić te Arhitektonskim studijem Fabijanić i Kincl d.o.o., 2011.). U vrijeme gradnje bio je najveća turistička investicija u Hrvatskoj, a visoko kategorizirani hoteli Lone i Monte Mulini označili su prekretnicu u tadašnjoj ponudi Rovinja $[15,16]$.

Volumen hotela Lone ima tlocrtni gabarit u obliku modificiranog slova „Y“ i smješten je u neposrednoj blizini hotela Eden. Zgrada ima 6 etaža (dvije podrumske + prizemlje + 3 kata) maksimalne visine 16,5 m iako zbog strmog terena djeluje niže. Hotel je interijerski zanimljivo koncipiran centralnim atrijskim prostorom koji se proteže kroz sve etaže te obuhvaća glavne komunikacije. Funkcionalno je objekt samo djelomično organiziran po etažama. Na dvije ukopane i u prizemnoj etaži miješaju se sadržaji (javno-društveni, gospodarski i smještajni trakt), dok se u tri nadzemne etaže nalazi isključivo smještajni trakt organiziran kao dvotrakt.

Na ulaznoj etaži nalaze se lobby bar, recepcija, bar, Vip salon, sobe za sastanke i mala dvorana sa 100 mjesta. Na etaži -1 smještena je trodijelna kongresna dvorana (600 mjesta), konferencijski bar, poslovni klub, glavni hotelski restoran, a na etaži -2 jazz klub, trgovine, dječji klub, wellness, i restoran. Parkiranje je riješeno garažom i vanjskim parkirnim mjestima. 


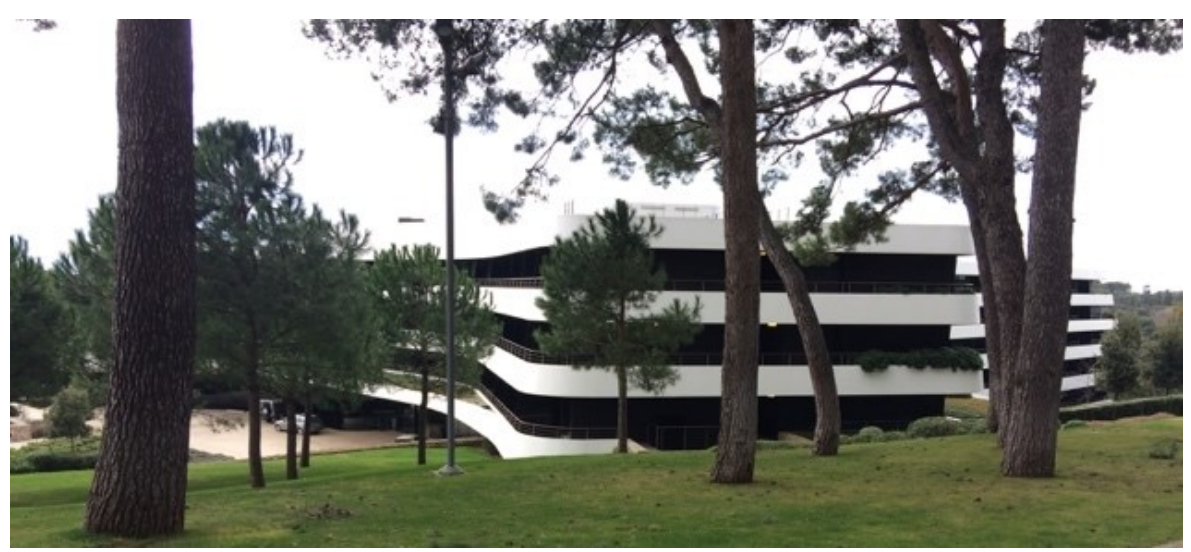

Slika 5. Ulaz Hotela Lone (Krošnjak, S.) [14]

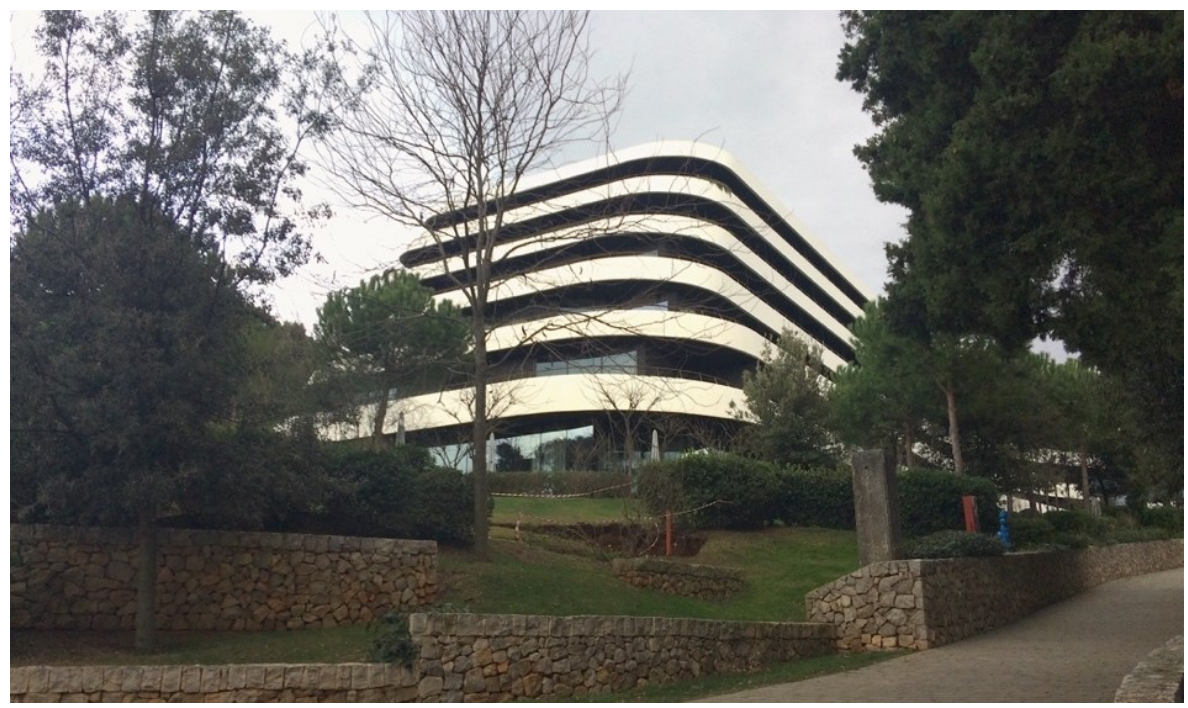

Slika 6. Hotel Lone (Krošnjak, S.) [14]

\subsection{Hotel Monte Mulini}

Hotel Monte Mulini nastao je na mjestu dvaju manjih depandansa sagrađenih šezdesetih godina, nepoznatog autora. Autorstvo današnjeg hotela potpisuje poduzeće Wimberly Allison Tong \& Goo projektom iz 2009., a izvedbeni projekt Otto Barić i poduzeće Arhitektura tholos projektiranje iz Zagreba. 


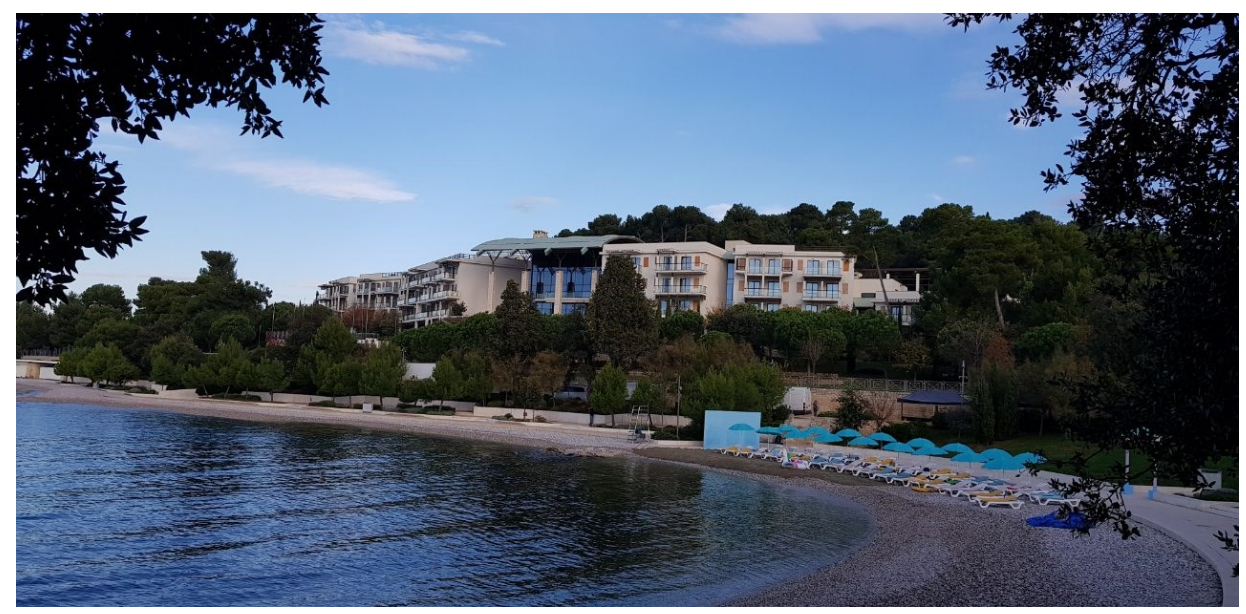

Slika 7. Hotel Monte Mulini (Matan C., 11.2018.)

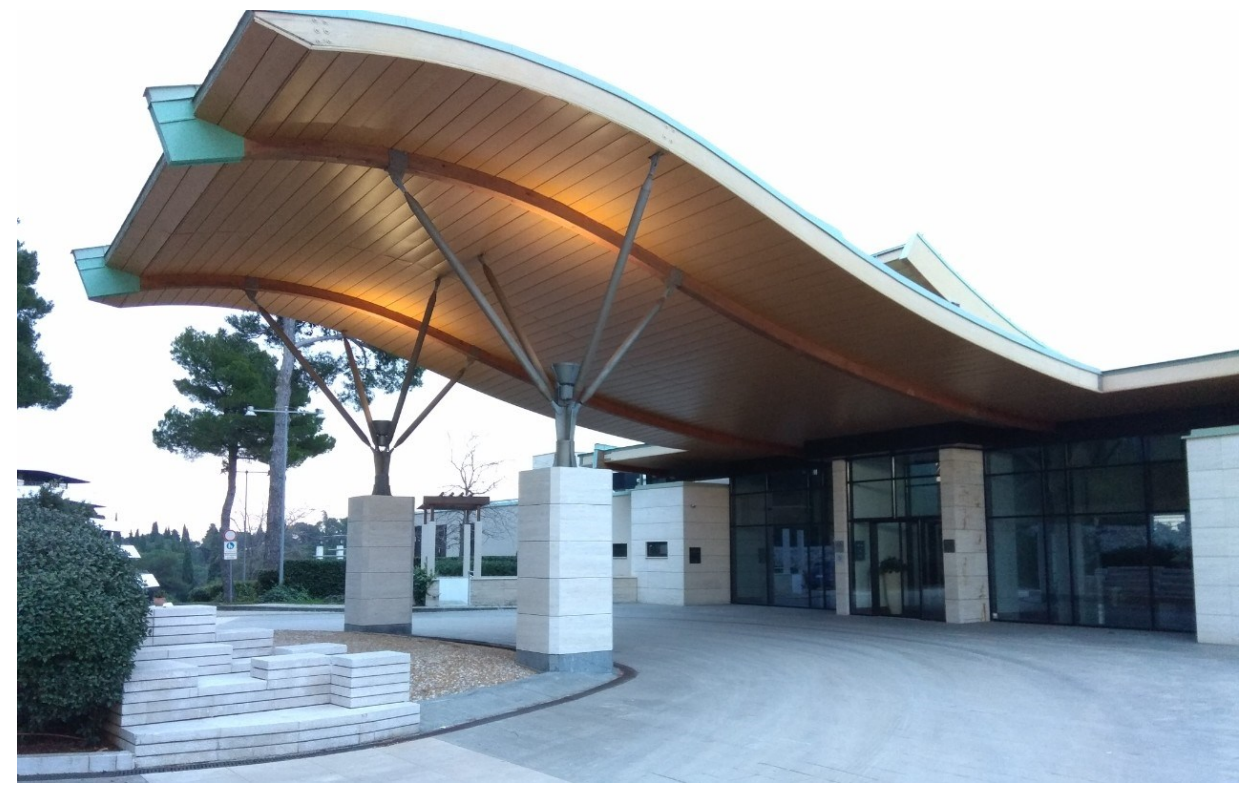

Slika 8. Ulaz hotela Monte Mulini (Matan C., 11.2018.)

Kolno-pješački prilaz i glavni ulaz u hotel sa sjeverne strane objekta nalaze se na razini trećeg kata. Hotel je sjevernom stranom ukopan te se spuštanjem na prizemnu etažu izlazi na južnu stranu prema bazenu i plaži. Oblikovanje hotela karakterizira razvedeni-volumen od 7 dijelova u nizu, svaki orijentiran prema najboljim vizurama. Hotel ima i dvije depandanse s pogledom na more i stari grad Rovinj.

Svi zajednički sadržaji hotela smješteni su u centralnoj zoni objekta, a smještajne jedinice organizirane su istočno i zapadno u razvedenim 
volumenima. Na etaži drugog kata nalazi se i wellness. Na prvom katu smješteni su restoran, kuhinja i spremišta. U prizemlju se nalazi hotelski bazen te drugi restoran. U zasebnoj depandansi hotela smješteni su dvoetažni apartmani s balkonima. Hotel ima podzemnu garažu u sjevernom dijelu objekta.

\subsection{Hotel Park}

Na parceli današnjeg hotela Parka nalazio se stariji hotel Sol Park koji je srušen. Novi hotel gradi se prema projektu Studija 3LHD [17,18], a rekonstrukcija ACI marine sastavni je dio projekta. Na istom je mjestu prvi hotel nepoznatog autora znatno manje površine bio izgrađen 1965., dok je 1985. godine sagrađen hotel Park kao rekonstrukcija i nadogradnja postojećeg prema projektu arhitekta Berislava Iskre te se paralelno oblikovala obala ispred hotela i sagradila marina. Hotel Park bio je kategoriziran sa 3 zvjezdice te je posljednji put renoviran 1999. godine.

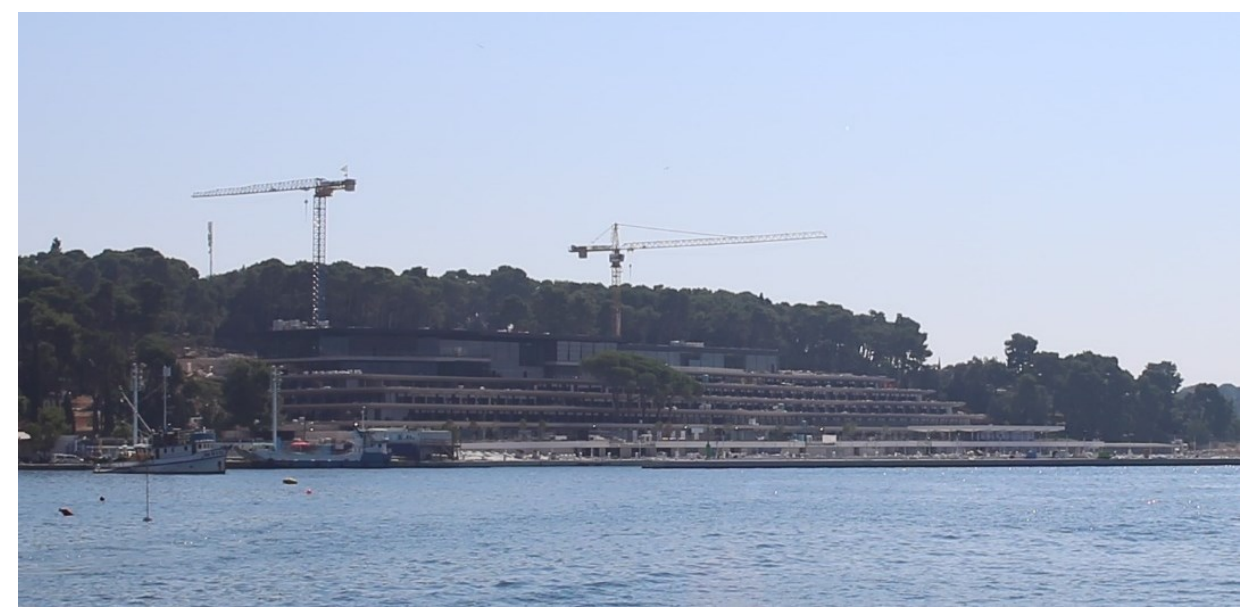

Slika 9. Hotel Park tijekom izgradnje (Matan C., 09.2018.)

Novi hotel Park s pet zvjezdica bit će poslovni gradski hotel površine od oko $3800 \mathrm{~m}^{2}$, otvoren cijele godine, za manje konferencijske skupove i događanja. Projekt predviđa 209 luksuznih smještajnih jedinica (sobe i apartmane), a sve smještajne jedinice trebale bi imati pogled na more i povijesnu jezgru Rovinja. Hotel će imati garažu sa oko 170 mjesta za goste i oko 180 mjesta javne namjene kao i stanicu za punjenje električnih automobila.

Građevina je koncipirana terasasto, nepravilnog je tlocrtnog oblika te se oblikovanjem prilagođava strmom terenu. Sastojat će se od 6 nadzemnih etaža od kojih su sve djelomično ukopane osim četvrte i pete. Ove dvije etaže sadrže glavne javno-društvene sadržaje hotela: glavni ulazni prostor, restorane i barove, kongresnu dvoranu te unutarnji i vanjski bazen sa 
wellnessom. Ističu se i oblikovanjem: zamišljene su kao paviljoni s dominantnim krovom. Na četvrtoj etaži će se uz navedene sadržaje naći i jedno krilo sa smještajnim jedinicama. Posebnost smještajnih jedinica su ozelenjeni krovovi i duboke strehe. Na razini šetališta i trga ispred hotela nalazit će se još jedan ulazni prostor za goste sa trgovačkim i ugostiteljskim sadržajima. Ozelenjivanjem terasa i krova objekt se nastoji uklopiti u okoliš, šumu koja ga okružuje [14].

\section{Opis značajki zone}

\subsection{Urbanističke karakteristike}

Zona Monte Mulini nalazi se južno od centra grada Rovinja na udaljenosti od svega nekoliko minuta hoda. Na sjeveru graniči s ACI marinom, na jugozapadu izlazi na more, a s južne strane nalazi se Park šuma Zlatni Rt i Park Škaraba, što su prednosti lokacije. Park šuma Zlatni Rt proglašena je 1948. godine prirodnom rijetkošću, a od 1961. godine uživa zaštitu u kategoriji park šume. Odlukom Grada Rovinja iz 1993. godine područje je Parkom Škaraba povećano na 14,5 ha. Sa sjeveroistočne strane zona graniči sa stambeno turističkom zonom novije izgradnje. Hoteli Monte Mulini, Lone i Eden urbanistički su stiješnjeni na relativno malenom prostoru, dok se Hotel Park nalazi dalje te je orijentiran na prostor Marine.

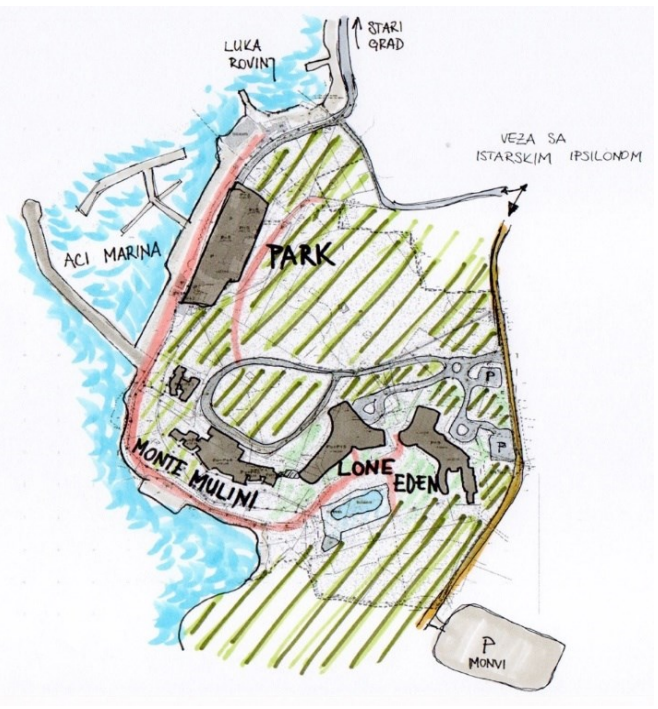

Slika 10. Zona Monte Mulini (analitička skica Krošnjak) - rekreacijski bazeni Hotela Monte Mulini (nisu ucrtani) nalaze se južno od Hotela Monte Mulini, smješteni prema moru [14] 
ACI marina Rovinj koji se nalazi ispred hotela Park rekonstruira se paralelno s hotelom. Time će ova marina postati prva u ACI sustavu $\mathrm{s}$ kategorizacijom od 5 sidara, što je najviša moguća.

\subsection{Osnovna prostorno-funkcionalna organizacija i datosti hotelskih zgrada}

Hotel Eden ima nepravilnu radijalnu organizaciju. Glavni ulaz u hotel na sjeveroistoku parcele postavljen je centralno u korpusu zgrade te je natkriven nadstrešnicom. Jednostruki volumen na sjeveru organiziran je kao dvotrakt, dva južna smještajna kraka organizirana su kao jednotrakt. Sobe su uglavnom orijentirane prema vanjskom bazenu i šumi. Javna i servisna namjena smještena je u suterenu i prizemlju, a dio zgrade podignut je na stupove. Sobe se nalaze u prizemlju i na višim etažama. Sve etaže imaju manji lobby uz glavne vertikalne komunikacije. Dio krova čine ozelenjene terase. Centar prostora je unutrašnje dvorište čija je atraktivnost smanjena slabijim uređenjem te standardiziranim pročeljem zgrade.

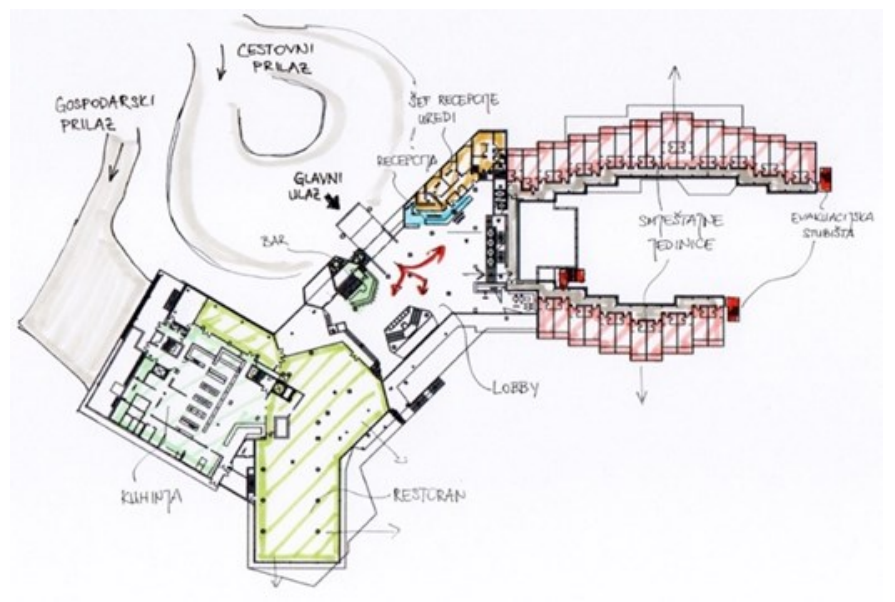

Slika 11. Tlocrt prizemlja Hotela Eden (analitička skica Krošnjak, S. prema Studio AD - projektna dokumentacija) [14]

Hotel Lone je također radijalne organizacije, s dužim krakom prema zapadu. Ulaz je također u sjeveroistočnom dijelu, a na južnoj strani nalazi se komunikacija prema vanjskim sadržajima. Osnovni sistem funkcionalne organizacije je dvotrakt, a atrij je centar komunikacije i mjesto okupljanja. Organizacija prostora podređena je konfiguraciji terena pa se u nižim etažama uglavnom nalaze javne (kongresne dvorane, restorani, garaža, wellness...) i servisne namjene, a smještaj na višim etažama. Ljepota uvale omogućuje atraktivne vizure. 


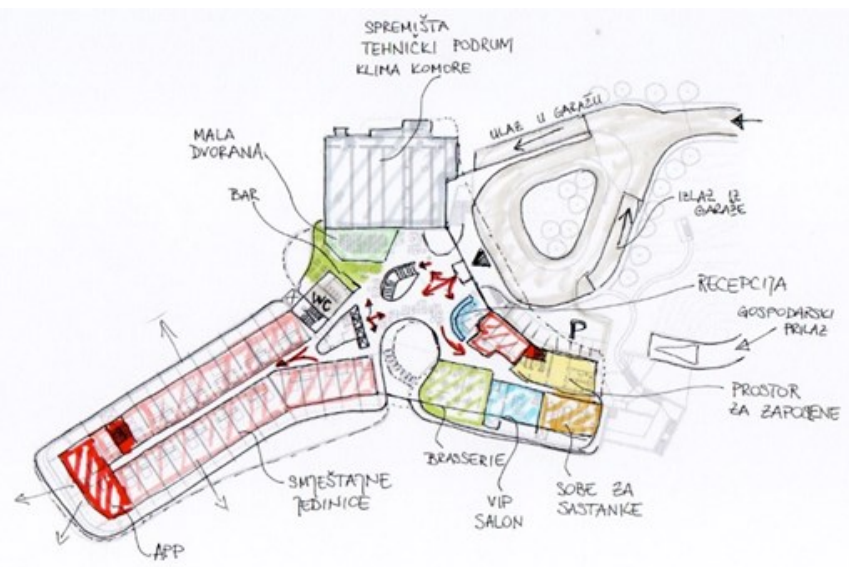

Slika 12. Tlocrt prizemlja Hotela Lone (analitička skica Krošnjak, S. prema Studio 3LHD - projektna dokumentacija) [14]

Hotel Monte Mulini u neposrednoj je blizini hotela Lone, ali je prvenstveno orijentiran prema plaži Mulini. Ispred hotela uređen je travnjak kao sunčalište uz bazen. Može se pratiti razvoj prostornih cjelina u osi hotel-bazeni-šetnica-plaža. Hotel se sastoji od jednog većeg volumena položenog u smjeru sjeverozapad-jugoistok i drugog manjeg postavljenog sa sjeverne strane. Sa sjeverne strane, gdje se nalazi glavni kolno-pješački pristup, vidljiva je samo jedna etaža hotela; centralno postavljen glavni ulaz naglašen je nadstrešnicom. Volumen hotela orijentiran je na južnu stranu. Sve sobe imaju pogled na more. Centralni dio je na svim etažama namijenjen komunikaciji i javnoj namjeni (npr. ulaz, restoran, bar...), a ostali dijelovi kompleksa su podijeljeni na zonu prema moru (smještaj) i zonu u terenu (servisni prostori, dio wellnessa i garaža). Krov je dijelom ozelenjen. Prostorna atrakcija interijera hotela je i u ovom slučaju dvoetažni atrij nadsvođen zakrivljenim svodom na stupovima te vizure.

Novi Hotel Park ima 6 nadzemnih etaža od kojih će četvrta i peta biti u potpunosti nadzemne, dok sve ostale imaju nadzemni i podzemni dio. Četvrta i peta etaža sadržavaju glavne javne sadržaje hotela. Na četvrtoj i nižim etažama nalaze se i smještajne jedinice. U podzemnom dijelu prostora smješteni su servisni prostori i garaža. U prizemlju se nalaze trgovačkougostiteljski sadržaji. Iskorištene su atraktivne vizure iz hotela. 


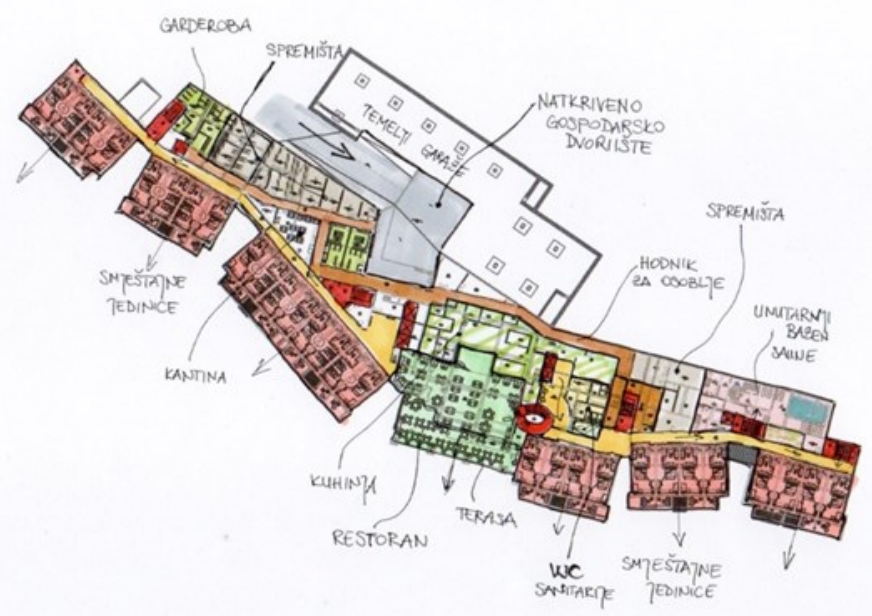

Slika 13. Tlocrt 1. kata Hotela Monte Mulini (analitička skica Krošnjak, S. prema Arhitektonski studio WATG - projektna dokumentacija) [14]

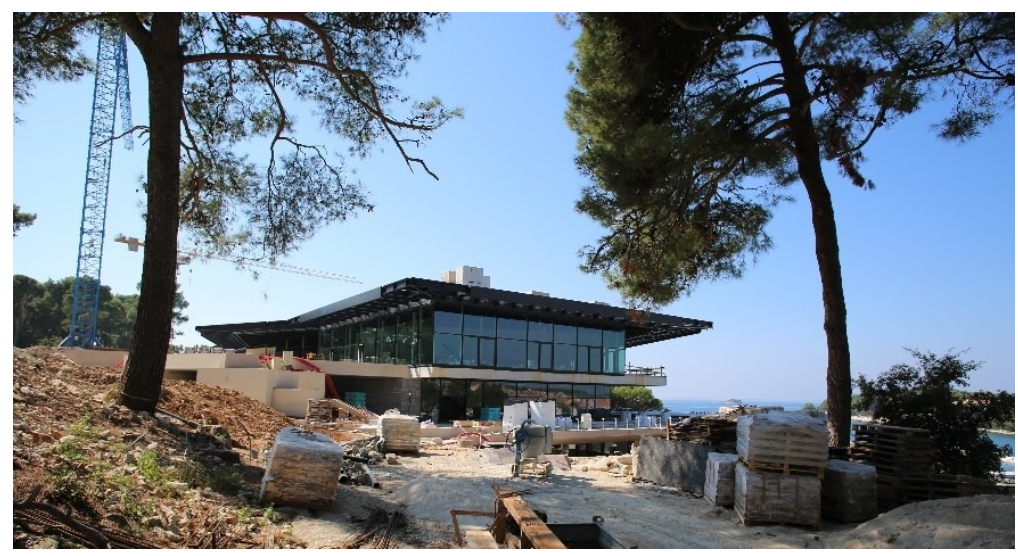

Slika 14. Izvedba radova na novom Hotelu Park (Matan C., 09.2018.)

\subsection{Smještajne jedinice}

Hotel Eden ima ukupno 325 soba različitih dimenzija (dvokrevetne sobe površine $24 \mathrm{~m}^{2}$, dvokrevetne s pomoćnim ležajem $26 \mathrm{~m}^{2}$ ) te 24 apartmana (veličine: $29 \mathrm{~m}^{2}, 46 \mathrm{~m}^{2}, 44 \mathrm{~m}^{2}$ ) sa spavaćim i dnevnim dijelom. Sve sobe imaju kupaonicu i balkon, jednostrano su ili dvostrano orijentirane. Radi privatnosti, višestrane organizacije i većih mogućnosti prostorno-funkcionalne organizacije, apartmani su smješteni na višim etažama na krajevima hodnika,.

Hotel Lone ima 248 smještajnih jedinica (173 dvokrevetnih soba, 63 spojene sobe, 11 apartmana i 1 predsjednički apartman) raspoređenih na 5 
etaža. Predviđeno je 5 soba prilagođenih osobama smanjene pokretljivosti, do svih soba omogućen je pristup liftom. Sobe na etaži 0 i -1 . su denivelirane u odnosu na javne sadržaje. Dimenzije soba su 33,17 $\mathrm{m}^{2}$ (s kupaonicom), nešto veće od propisanih veličina soba za hotele s 5 zvjezdica prema postojećoj regulativi [12]. Apartmani se nalaze na višim etažama $s$ direktnim pogledom na otoke i more. Sobe su jednostrano i dvostrano orijentirane, a imaju terase sa pogledom na šumu. Veličina terasa je veća na donjim etažama. Na etaži -1 ugrađene su vanjske masažne kade na terasama soba koje gledaju na bazene Monte Mulini.

Hotel Monte Mulini ima 113 smještajnih jedinica (od toga 104 sobe: veličine $39 \mathrm{~m}^{2}$, obiteljske sobe $78 \mathrm{~m}^{2}$, apartmani od $56 \mathrm{~m}^{2}$ do $84 \mathrm{~m}^{2}$ ), sve veće od uvjeta propisanih regulativom [12]. U zasebnoj depandansi hotela smješteni su apartmani. Dio apartmana je dvoetažni (duplex) - sobe se nalaze na donjoj etaži, a na gornjoj se nalazi dnevni dio. Sve etaže imaju izlaz na balkon i kupaonice s WC-ima.

Projektom Hotela Park predviđeno je 209 luksuznih smještajnih jedinica (190 soba i 20 apartmana). Nije bilo moguće doći do informacija o veličini soba, no neki od apartmana imaju predviđene i nadstandarde kao što su zasebne garderobe te duplex organizaciju i ozelenjeni vrt. Smještajne jedinice imaju pogled na more i povijesnu jezgru.

\subsection{Konstrukcija}

Hotel Eden ima armiranobetonsku konstrukciju (stupovi, zidovi prosječne debljine $15 \mathrm{~cm}$ ). Na konstrukciji zadnje etaže izrađena su ojačanja nosivih ploča jer se povećalo opterećenje krovova izvedbom zelenih krovova. Pregradni zidovi su debljine $12 \mathrm{~cm}$. Stubišta su armiranobetonska. Krovovi su ravni, nepromijenjeni radovima redovnog održavanja, osim djelomičnog ozelenjivanja. Konstrukcija Hotela Lone je armiranobetonska, osim konstrukcije krova atrija koja je čelična. Konstrukcija je zahtjevna zbog dužine zgrade, velikih raspona, i složenih sklopova koji se protežu u više etaža te imaju promjenjivu strukturu (ploče, grede, stupovi, zidovi, konzole...). Posebno je zahtjevna konstrukcija grednih nosača dvorane (preko 19,5 m), zidova u zoni promjene ravnina i visokostijenih nosača konzole (5 m).

Konstrukcija zgrade Hotela Monte Mulini je armiranobetonska, osim konstrukcije krova atrija koja je čelična. Kod smještajnih jedinica koristi se sistem nosivih armiranobetonskih zidova, dok je centralni dio karakterističan po sistemu stupova koji nose zaobljenu čeličnu rešetkastu konstrukciju. Konstrukcija Hotela Park je armiranobetonska s naglašenim konzolama terasa na vertikalnim platnima, a krov gornje etaže je u čeličnoj konstrukciji kao i ulazna nadstrešnica. 


\subsection{Oblikovanje}

Hotel Eden oblikovan je nepravilno, u formi slova „Y“, zgrada je u južnom dijelu podignuta na stupove, a na gornjim razinama se razvija terasasto. Dva kraka „Y“-a čine unutrašnje dvorište iz kojeg se djelomično pruža pogled prema bazenu (ispod zgrade). Fasada dvorišta je ostakljena. Ostala pročelja imaju pravilan raster na kojem je naglašena horizontalnost s loggiama (ožbukana $A B$ konstrukcija), prekidana lomovima volumena. Gornje etaže se terasasto snižavaju prema jugu, dio krova su ozelenjene terase. Hotel Lone također je oblikovan radijalno, dok pročelja karakteriziraju neprekinute horizontale loggie iza kojih se nazire staklena fasada. Parapeti loggia obloženi su pločama od recikliranog ekspandiranog staklenog granulata, pričvršćenih na čeličnu podkonstrukciju koja prati zakrivljen tlocrtni oblik. Terase su nakošene i sužavaju se prema najvišoj etaži, radi čega hotel podsjeća na brod. Ulaz u hotel nalazi se $u$ sjeveroistočnom dijelu volumena, uvučen u tijelo zgrade. Centralni dio interijera građevine karakterizira atrij kroz cijelu visinu zgrade, ostakljeni krov atrija prepoznaje se i kao jedna od karakteristika zgrade iz zraka.

Hotel Monte Mulini organiziran je u 7 međusobno povezanih volumena u nizu, dok je osmi izvan ove linije. Svaki je orijentiran prema plaži. Korpusi smještajnih jedinica izvana su klasično ožbukani s detaljima boje breskve i balkonima sa staklenom ogradom. Centralni volumen građevine naglašen je stupovima duž cijele visine i nadstrešnicom koja nadsvođuje vanjsku terasu. Pročelje centralnog volumena je ostakljeno. Hotel Park koncipiran je terasasto, nepravilnog tlocrtnog oblika. Zgrada se prilagođava konfiguraciji terena. U oblikovanju dominiraju većinom ozelenjene horizontale terasa javnih i privatnih prostora, dok su pročelja ostakljena i duboko uvučena. Najdominantnije je zapadno pročelje radi impozantnih dimenzija. Na građevini se iščitavaju dvije cjeline: smještajna s ozelenjenim krovovima i dubokim strehama te javni prostori s otvorenijim terasama.

\subsection{Oblikovanje i materijali u unutrašnjem prostoru}

Oblikovanje interijera javne zone Hotela Eden karakterizirano je klasičnim reprezentativnim materijalima kao što su kamen, drvo i staklo, a strop ima pravokutni raster koji se prenosi i na oblikovanje eksterijera zgrade. Podovi hodnika završno su obloženi tepisonom i keramičkim pločicama. Sobe su obložene tepisonom, a kupaonice u sobama keramikom.

Osnovna atrakcija unutrašnjeg prostora Hotela Lone je centralni atrij kroz cijelu visinu zgrade, iz kojeg se pružaju pogledi na interijer i eksterijer. Posebno je to izraženo u prizemlju gdje je atrij otvoren prema različitim pročeljima (sjeveroistočnom i južnom). Interijersko uređenje hotela plod je suradnje mnogih hrvatskih dizajnera. Kao i na vanjskim pročeljima, u interijeru su linije zaobljene, prevladava bijela boja, a pojavljuju se i 
kontrastne boje. U hodnicima i sobama postavljen je tepison radi smanjenja buke. Osim žbuke na zidovima, pojavljuju se i drvene obloge.

U Hotelu Monte Mulini, podovi su obloženi tepisonom i keramikom, te drvenom oblogom. Podovi soba obloženi su svijetlim tepisonom, a zidovi bojani i obloženi drvenim oblogama. Restoran je uređen kao konoba pa prevladavaju tradicionalni materijali: opeka, žbuka, kamen. Svodovi su obloženi opekom.

Podovi javnih prostor Hotela Park obloženi su venecijanskim teracom, kamenom i keramikom, a voda je korištena kao element oblikovanja interijera - razina vode u javnim bazenima je postavljena u razini poda tako da voda postaje jedan od materijala obloge, gdje oblik bazena postaje obris u linijama poda ili izduženi element koji povezuje vanjski i unutrašnji prostor. Također, voda omogućava i zrcaljenje ploha zidova i obogaćuje teksture površina u prostoru. Osim u zajedničkim prostorima, voda obogaćuje i dio privatnih smještaja (npr. apartmani organizirani na dvije etaže) gdje su na terasama smješteni bazeni prema kojima pogled seže iz unutrašnjosti apartmana kroz staklene stijene koje se nalaze u cijeloj širini apartmana. Zidovi su ožbukani, bojani različitim bojama te oblagani kamenom ili grafički obrađenim vidljivim betonom. Interijer obogaćuju elementi dekora (umjetnička rasvjeta...), a stubište također postaje dekorativni element. Stropovi su obrađeni različitim materijalima, ovisno o namjeni prostora (bambus, drvo). U sobama su površine završno obrađene kamenom, žbukom i drvenim oblogama te tepisima, neprozirnim staklom i plastikom.

\subsection{Vanjski sadržaji}

Hoteli Eden i Lone smještajem i oblikovanjem čine jedinstven prostor $\mathrm{u}$ istočnom dijelu zone u čijem se centru nalazi veliki zajednički vanjski rekreacijski bazen $\left(1054 \mathrm{~m}^{2}\right)$, postavljen južno od Hotela Lone, a sastavljen od četiri bazena međusobno povezana slapom i još dva dječja bazena. Bazen se nalazi na udaljenosti od $50 \mathrm{~m}$ od Hotela Lone i skoro $90 \mathrm{~m}$ od Hotela Eden. Uz bazen je izvedeno $2350 \mathrm{~m}^{2}$ terasa-sunčališta (200 ležaljki) u šest nivoa koji prate teren. Pod je obložen kamenom i dijelom ozelenjen. Sa sunčališta se pruža pogled prema moru. Oblikovanje vanjskih restorana karakterizira upotreba drva kao podnih, zidnih i stropnih elemenata (na čeličnoj konstrukciji).

Hotel Monte Mulini ima svoj bazen (rekreacijski bazen $235 \mathrm{~m}^{2}$, donji bazen $64 \mathrm{~m}^{2}$, dječji bazen $55 \mathrm{~m}^{2}$, topli bazen $25 \mathrm{~m}^{2}$ ). Bazeni su okruženi sunčalištem obloženim kamenim i drvenim oblogama $\left(400 \mathrm{~m}^{2}\right)$ te ozelenjenim površinama. Uz bazene je smješten i pomoćni objekt s barom. U sklopu hotela uređena je i plaža Monte Mulini, dijelom u betonu, a dijelom u šljunku. Na plaži se nalazi kafić sa sanitarijama i svlačionicama, pokriven pergolom čelične konstrukcije, modelirane prema kretanju svjetlosti. 
Hotel Park projektiran je kao hotel u šumi, element zelenila je dominantan. Pod vanjskih terasa obložen je drvetom i kamenom, zidovi kamenom, dok su nadstrešnice drvene, a sjenila od tkanina. Voda je važan element oblikovanja prostora, a korištenje različitih rekreacijskih bazena olakšavaju sunčališta i drvene platforme. Osim uređenja terasa, karakterističan je i otvoreni prostor uz javno šetalište zamišljen kao prostor gradskog okupljanja nadopunjen trgovačkim i ugostiteljskim sadržajima hotela Park.

\subsection{Pročelja}

Pročelja Hotela Edena karakterizira konstrukcijski raster koji na sjeveroistočnom pročelju teče neprekinut, dok je na jugozapadnom pročelju izlomljen $u$ širini 2 jedinice. Unutrašnje dvorište ostakljeno je strukturalnom fasadom. Kod Hotela Lone velika pozornost dana je vanjskom oblikovanju samog volumena, a izgled zgrade karakteriziraju horizontale parapeta soba. Fasada hotela je žbukana, dok su uvučeni dijelovi fasade ostakljeni tamnim staklom.

Kod Hotela Monte Mulini najupečatljivije je morsko pročelje na kojemu se prepoznaju volumeni smještajnih jedinica i centralni volumen s atrijem koji ima ostakljenu fasadu i nosive stupove s ekspresivnom nadstrešnicom. Kod Hotela Parka ozelenjivanje zgrade osnovna je tema projekta pa je element zelenila dominantan i u oblikovanju građevine. Horizontalne terase omogućavaju uklapanje zgrade u parkovno uređen okoliš.

\section{Rasprava}

Područje Rovinja ima dugu povijest turizma, a posljednjih desetljeća se kontinuirano ulaže u poboljšanje i povećanje turističkih kapaciteta. Rekonstrukcije i izgradnje novih građevina te uređenje prostora (plaže, marina) rade se $s$ ciljem poboljšanja kvalitete ponude. Zaštita okoliša je planirana prostorno planskom dokumentacijom i konzervatorskom zaštitom (kategorija: park šuma Zlatni rt, povijesna jezgra Grada Rovinja). Ekskluzivnost ovog prostora povezana je osim toga i sa blizinom mora.

$\mathrm{Na}$ ostvarivanje cilja visokokvalitetne ponude, osim samog smještaja, utječe i ponuda u blizini (koja bi trebala biti na istoj razini kvalitete, a često ne ovisi direktno o investitorima u zoni) te infrastruktura (blizina zračne luke, autoceste...) u koju treba ulagati. Turistička ponuda u unutrašnjosti Istre dijelom nadoknađuje nedostatke sadržaja u okolici zone Monte Mulini ruralnim turizmom (kulturna i kulinarska ponuda). Pored dobrobiti za lokalnu zajednicu, negativna strana turizma jest trajna potrošnja prostornih resursa. Na zračnoj snimci (Slika 1) može se prepoznati drastično povećanje izgrađenih volumena te posljedično smanjenje površine zelenih površina. Povećanjem izgrađenosti, također je izmijenjena vizura iz povijesne jezgre. 
U prostorno funkcionalnoj organizaciji i oblikovanju analiziranih objekata pojavljuju se nekoliko arhitektonskih elemenata: radijalna organizacija, linearna organizacija, naglašene horizontale, razlomljenost pročelja, prilagodba konfiguraciji terena, ozelenjivanje pročelja kao svojevrsna kompenzacija smanjenju površine šume. Karakterističan je i raspored javnih sadržaja i smještaja kroz više različitih etaža kako bi se najbolje iskoristila pročelja, a servisne prostore ukopalo u teren. Smještaj ulaza u centralnom dijelu zgrade naglašen je u vanjskom i unutrašnjem izgledu (npr. atriji hotela Lone i Monte Mulini).

U smještajnim dijelovima vidljivo je značajno povećanje standarda. Tako površine soba od $25 \mathrm{~m}^{2}$ i apartmana od $44 \mathrm{~m}^{2}$ Hotela Eden rastu do $39 \mathrm{~m}^{2}$ za standardne sobe te do $84 \mathrm{~m}^{2}$ za apartmane (u novijim hotelima), što je dvostruko povećanje. Također se pojavljuju apartmani duplex organizacije i posebna oprema - vanjske masažne kade za svaku sobu, vanjski vrtovi, garderobe. Značajno povećanje standarda vidljivo u povećanju dimenzija soba utječe na povećanje ukupnih površina i volumena građevina te se može zaključiti da je značajno povećanje volumena (i posljedični utjecaj na prostor) direktno povezano sa višom kategorizacijom kao i povećanjem hotelskih standarda u odnosu na vrijeme izgradnje postojećih hotela te potrebama poslovanja hotela, odnosno da sam cilj poboljšanja ponude utječe na kontrastan učinak u odnosu na traženo.

Osnovna konstrukcija svih građevina je armiranobetonska, dok su neki dijelovi zgrada izvedeni kao čelični, i to često u najreprezentativnijim zonama građevina (npr. atriji, ulazne nadstrešnice itd.). U unutrašnjim prostorima javljaju se većinom tradicionalni materijali - kamen, drvo, keramika, žbuka, opeka... a u novijim hotelima se pojavljuju kombinacije sve većeg broja materijala u javnim, ali i u smještajnim prostorima. Dok su vanjski sadržaji hotela Eden i Lone uglavnom karakterizirani upotrebom kamena, u novijim hotelima se pojavljuju kombinacije materijala kamendrvo-zelenilo, a voda ima sve veću ulogu u definiciji površina u unutrašnjem i vanjskom prostoru. Također se velika pažnja posvećuje atrakcijama, posebno razvoju prostora u visinu i pogledima - fokus pogleda je plaža, more, šuma i povijesna jezgra.

\section{Zaključak}

Povećanjem važnosti turizma za nacionalnu ekonomiju, ulaže se u povećanje kapaciteta i kvalitetu turističkog smještaja, što se također može vidjeti i u jednoj od najvažnijih turističkih zona Hrvatske, zone Monte Mulini, gdje se ekskluzivnost smještaja povezuje s prirodnom i povijesnom baštinom (more, park šuma, povijesna jezgra).

Analizom značajki ove zone može se zamijetiti da ovaj pristup ima svoje pozitivne, ali i negativne strane - značajno povećanje izgrađenih volumena 
(zbog povećanja standarda, ali i ukupnih kapaciteta), dovodi i do smanjenja kvalitete prirodnog i kulturnog okoliša pa se postavlja pitanje kapaciteta nosivosti prostora (carrying capacity) te uloge zaštite javnih i zajedničkih dobara koji su i bili osnovni poticaj za smještaj hotela. Danas se, osim u smanjenju zelenih površina, ova ograničenja ogledaju i u gustom urbanističkom rješenju zone te $u$ velikom broju posjetitelja obzirom na mjerilo grada i šume. Nije u potpunosti jasno je li i koliko je smanjenje kvalitete i količine prostornih resursa rezultiralo i povećanjem kvalitete života za lokalnu zajednicu.

Pored svojevrsne kompleksnosti funkcionalnog rješenja hotela uvjetovanog konfiguracijom terena, analizirajući oblikovanje i konstrukcije mogu se uočiti određene teme (horizontale, centralnost ulaza, kombinacija armiranobetonske i čelične konstrukcije...) te njihov razvoj, no u konstrukcijskom smislu ne rade se veći iskoraci. Nasuprot tome, standard (dimenzije i oprema, raznovrsnost materijala...), prostorna organizacija te uređenje unutrašnjih i vanjskih prostora povećavaju se sa svakim novim hotelom.

\section{Literatura}

[1] Blažević, I. (1987) Povijest turizma Istre i Kvarnera. Opatija: Otokar Keršovani.

[2] Zadel, Z., Rudan, E. (2015) Retrospektiva turizma Istre. Kopar: Založba Univerze na Primorskem.

[3] Magaš, B. (1963.-1997) Zgrade hotelske, Tehnička enciklopedija. Zagreb: Leksikografski zavod Miroslava Krleže.

[4] Turistička zajednica grada Rovinja Rovigno, http://www.tzgrovinj.hr pristup 16.09.2018.

[5] Mutnjaković A. (uredio) (2014) Identitet jadranske turističke arhitekture. Međunarodni znanstveni skup: „Zbornik radova“. Zagreb: HAZU.

[6] Curić, Z., Glamuzina, N., Opačić, V.T. (2013) Geografija turizma: regionalni pregled. Udžbenici Sveučilišta u Zagrebu. Zagreb: Naklada Ljevak.

[7] Turistička zajednica Istarske županije. Službeni turistički portal Istre. http://www.istra.hr (18.09.2018.)

[8] DPU turističke zone Monte Mulini, Sl. glasnik Grada Rovinja br. 08/06. http://www.rovinj-rovigno.hr/prostorno-uredenje-gradnja-iokolis/dokumenti-prostornog-uredenja/planovi-na-snazi/detaljni-planuredenja-turisticke-zone-monte-mulini// (18.09.2018.)

[9] Google Earth, https://earth.google.com/web/ (18.09.2018.)

[10] Istrapedia. http://istrapedia.hr/hrv/1113/hutterott-johann-georg/istra-a-z/ (18.09.2018.)

[11] Maistra Hospitality Group. https://www.maistra.com (09.2018.)

[12] Pravilnik o razvrstavanju, kategorizaciji i posebnim standardima ugostiteljskih objekata iz skupine hoteli (NN 88/07, 58/08, 62/09). 
[13] Bobovec, B., Korlaet, L., Virag, N. (2015) Arhitekt Ivo Bartolić; Prolegomena opusu. Prostor, vol. 23, br. 1 (49), 2015, str. 160-173. https://hrcak.srce.hr/140963. (18.09.2018.)

[14] Krošnjak, S. (2018) Suvremena turistička izgradnja u području Rovinja, Istra. Diplomski rad. Rijeka: Sveučilište u Rijeci. Građevinski fakultet.

[15] 3LHD. Hotel Lone. http://www.3lhd.com/en/project/hotel-lone (09.2018.)

[16] "Lone Hotel/3LHD" 03 Aug 2011. ArchDaily. Accessed 18 Oct 2018. <https://www.archdaily.com/155584/lone-hotel-3lhd/> ISSN 0719-8884; http://zse.hr/userdocsimages/prospekti/MAIS-prospekt.pdf (24.11.2018.)

[17] 3LHD. Hotel Park. http://www.3lhd.com/en/project/hotel-park (09.2018.)

[18] Lissoni associati. https://www.lissoniassociati.com/en/architecture/hotelresorts/hotel+park,+rovini/325 (10.2018.) 